\title{
Pękanie spawanych ścian szczelnych podczas eksploatacji
}

\section{Cracking of welded membrane walls during operation}

\section{Streszczenie}

W pracy przedstawiono wyniki badań przyczyn pękania ścian szczelnych kotłów gazowych podczas eksploatacji. Zakres badań obejmował badania metalograficzne oraz badania twardości. Ujawnione struktury pozwoliły w jednoznaczny sposób określić przyczynę uszkodzenia ścian szczelnych spawanych hybrydowo. Stwierdzono, że przyczyną pękania była korozja naprężeniowa, spowodowana równoczesnym oddziałaniem statycznych naprężeń rozciągających i środowiska korozyjnego.

Słowa kluczowe: spawanie hybrydowe; ściana szczelna; laser

\begin{abstract}
The paper presents the results of research into the causes of cracking in gas boiler membrane walls during service. The scope of the study included metallographic examinations and hardness tests. The structures revealed made it possible to determine unambiguously the cause of damage to hybrid-welded membrane walls. It was found that cracking had been caused by stress corrosion resulting from the simultaneous action of static tensile stresses and a corrosive environment.
\end{abstract}

Keywords: hybrid welding; membrane wall; laser

\section{Wstęp}

Ściany szczelne (gazoszczelne) zwane również membranowymi, stosowane są m.in. w nowoczesnych kotłach wodnorurkowych, gwarantując szczelność kotła po stronie spalin i zwiększając ogólną sprawność kotła. Wytwarzanie ścian szczelnych polega na połączeniu elementów płaskownik-rura-płaskownik-itd. (ok. 12 rur) w tzw. panele o długości do $25 \mathrm{~m}$. Do najczęściej stosowanych technologii spawania paneli ścian szczelnych zaliczyć należy zautomatyzowane spawanie łukiem krytym.

W firmie Energoinstal do łączenia poszczególnych elementów panelu stosuje się jedną z najnowszych technologii spawania - spawanie hybrydowe Laser+MAG (rys. 1b). Połączenie rura-płaskownik-rura odbywa się w dwóch przejściach tj. wykonanie spoiny doczołowej jednostronnej, następnie obrót elementu i wykonanie spoiny z drugiej strony. Prędkość spawania zależy przede wszystkim od gatunku zastosowanego materiału podstawowego oraz jego grubości i mieści się w przedziale od 3 do $4 \mathrm{~m} / \mathrm{min}$. Porównanie makrostruktury połączenia rura-płaskownik wykonanego łukiem krytym i metodą hybrydową pokazano na rysunku 1 [1].

Do korzyści z zastosowania tej innowacyjnej technologii należy, nie tylko zwiększenie prędkości spawania, ale również, znaczące poszerzenie możliwości produkcyjnych. Nowa technologia spawania charakteryzuje się bardzo wąską strefą wpływu ciepła (poniżej $1 \mathrm{~mm}$ ), co pozwala na redukcję grubości ścianki rury, przy zapewnieniu co najmniej $2 \mathrm{~mm}$ materiału nieobrobionego cieplne. Umożliwia to redukcję masy ścian szczelnych w kotle nawet do 30\%. Kolejną zaletą tej technologii jest możliwość łączenia elementów o różnych grubościach, np. rury ze ścianką o grubości $3 \mathrm{~mm}$ i płaskownika o grubości $8 \mathrm{~mm}$. Wykonanie takiego połączenia w przypadku spawania metodą konwencjonalną tj. łukiem krytym, spełniającego wymagania przepisów technicznych (np. PN EN ISO 12952 [2], VGB-R 501 H [3]) jest bardzo utrudnione ze względu na szerokość SWC i możliwość przepalenia rury. Również do zalet nowej metody spawania należy zaliczyć możliwość spawania paneli ścian szczelnych z bardzo małą podziałką, tj. szerokością płaskownika nieprzekraczającą $20 \mathrm{~mm}$ (rys. 2).

Zastosowanie nowych technologii wytwarzania elementów dla energetyki wymaga jednak nie tylko opracowania i kwalifikowania procesu spawania, ale również uwzględnienia zmian w konstrukcji kotła przez projektantów i konstruktorów. Dotyczy to np. zmniejszenia masy kotła i zmiany naprężeń i odkształceń podczas eksploatacji.

\section{Materiał do badań}

Do badań przyczyny ujawnionych pęknięć rur paneli ścian szczelnych wykorzystano próbki wycięte z uszkodzonych fragmentów ściany szczelnej. Miejsce wycięcia próbek pokazano na rysunku 3. Zgodnie z dokumentacją rura o średnicy 76,1 x $4 \mathrm{~mm}$ została wykonana ze stali P265GH TC1

Dr hab. inż. Janusz Adamiec - Politechnika Śląska.

Autor korespondencyjny/Corresponding author. janusz.adamiec@polsl.pl 

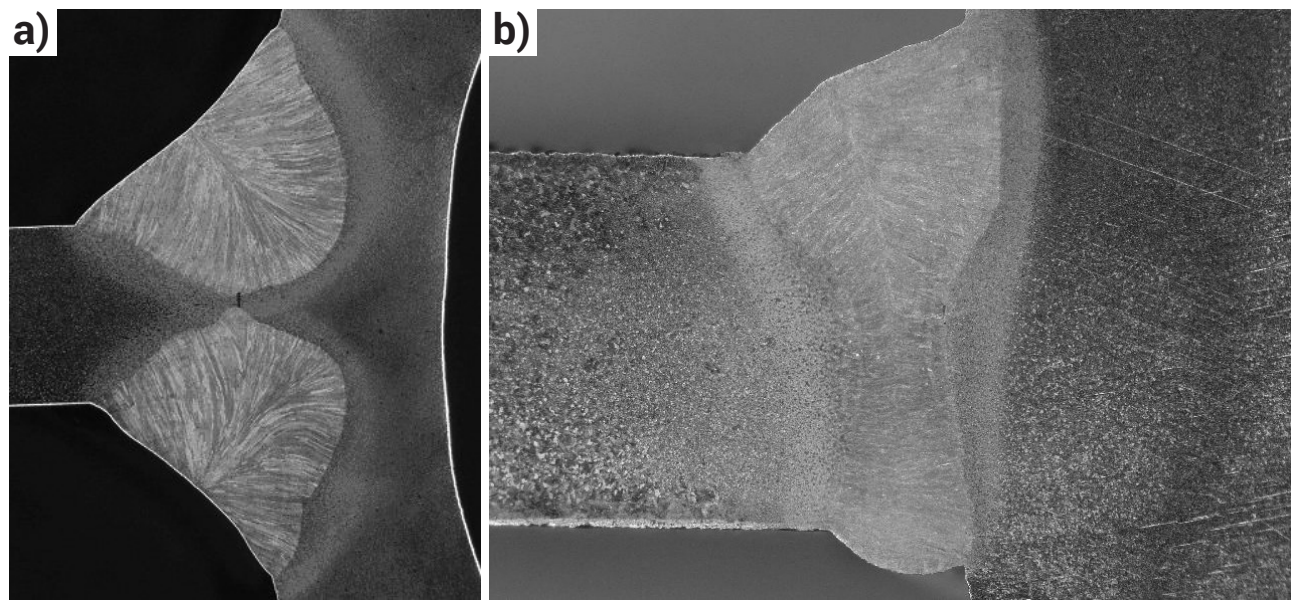

Rys. 1. Złącze doczołowe rura (P235JRG2 $\varnothing 57 \times 5 \mathrm{~mm}$ )płaskownik (S235JRG2 $20 \times 5 \mathrm{~mm}$ ) panelu ściany szczelnej: a) wykonane łukiem krytym, b) spawane hybrydowo: laser włóknowy+MAG Fig. 1. Tube (P235JRG2 ø57 x 5 mm) -flat bar (S235JRG2 $20 \times 5 \mathrm{~mm}$ ) butt joints of membrane wall panels: a) SAW-welded, b) hybrid-welded: fibre laser+MAG

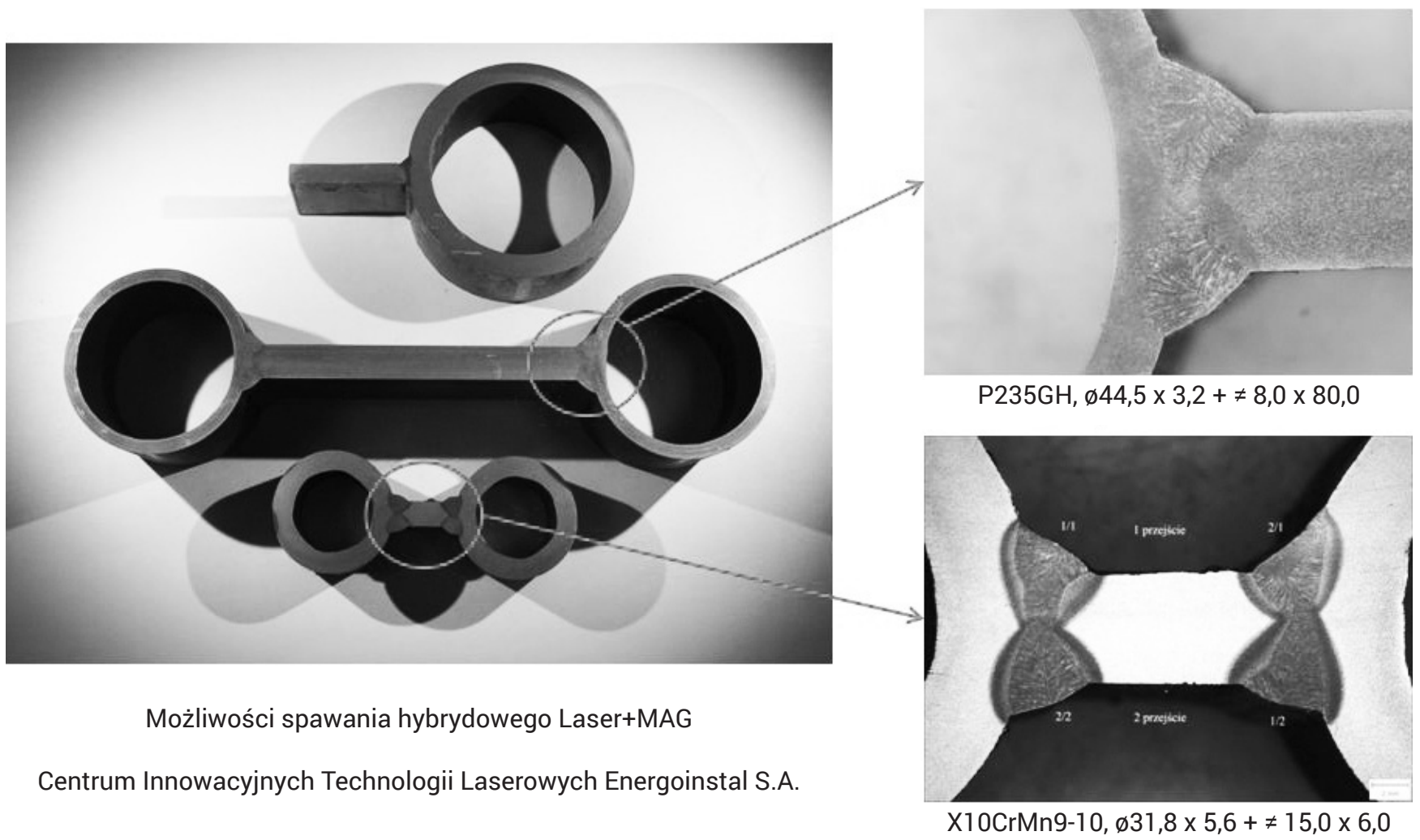

Rys. 2. Nowe możliwości spawania paneli ścian szczelnych metodą hybrydową Laser+MAG

Fig. 2. New possibilities of welding membrane wall panels by the laser+MAG hybrid welding technology

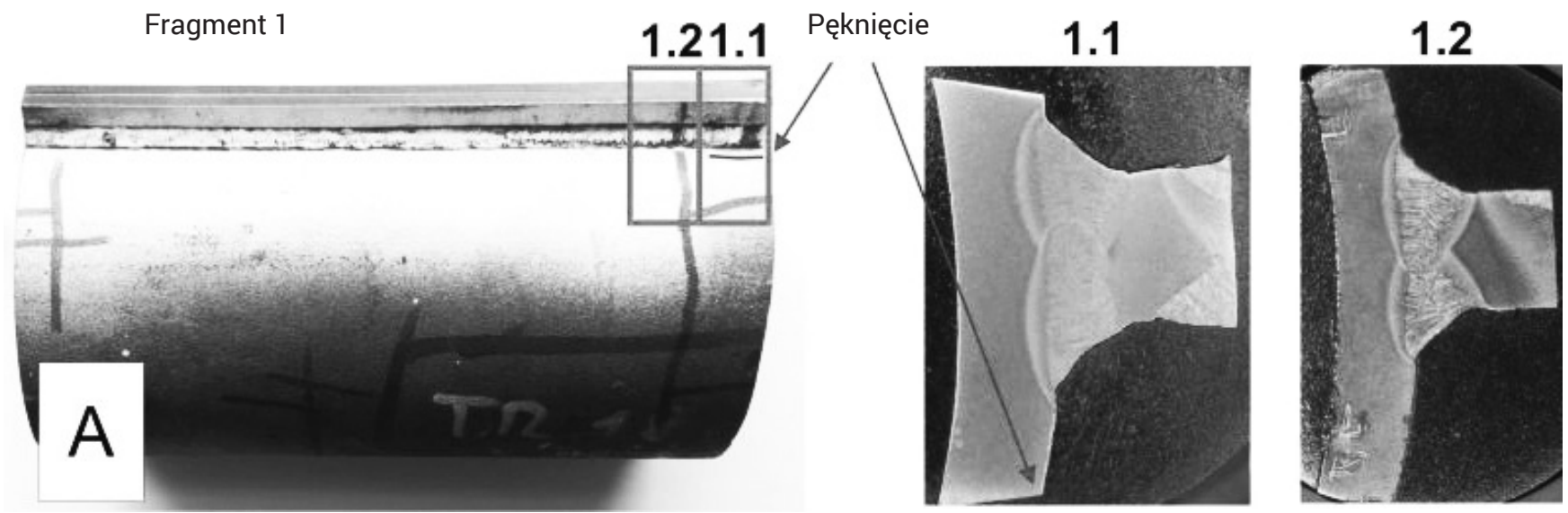

Rys. 3. Miejsce pobrania próbek do badań przyczyny uszkodzenia

Fig. 3. Place of sampling for the purposes of the research into the cause of the damage 
a płaskownik o grubości 6 mm był ze stali P265. Rury z płaskownikiem były spawane dwustronnie z pełnym przetopieniem metodą hybrydową (Laser+MAG) wg zakwalifikowanej technologii.

\section{Badania struktury złączy spawanych hybrydowo}

Do badań strukturalnych przygotowano zgłady metalograficzne, które następnie były trawione w 5\% nitalu przez $10 \mathrm{~s}$. Wstępne obserwacje struktury wykonano na mikroskopie stereoskopowym Olympus ZSX9 (SM) przy powiększeniach do 50x. Wyniki tych obserwacji pokazano na rysunku 4. Badania przy powiększeniach do 500x wykonano na mikroskopie świetlnym (LM) Olympus GX71 w technice pola jasnego (rys. 5). Uzupełnieniem badań metalograficznych były badania struktury na elektronowym mikroskopie skaningowym
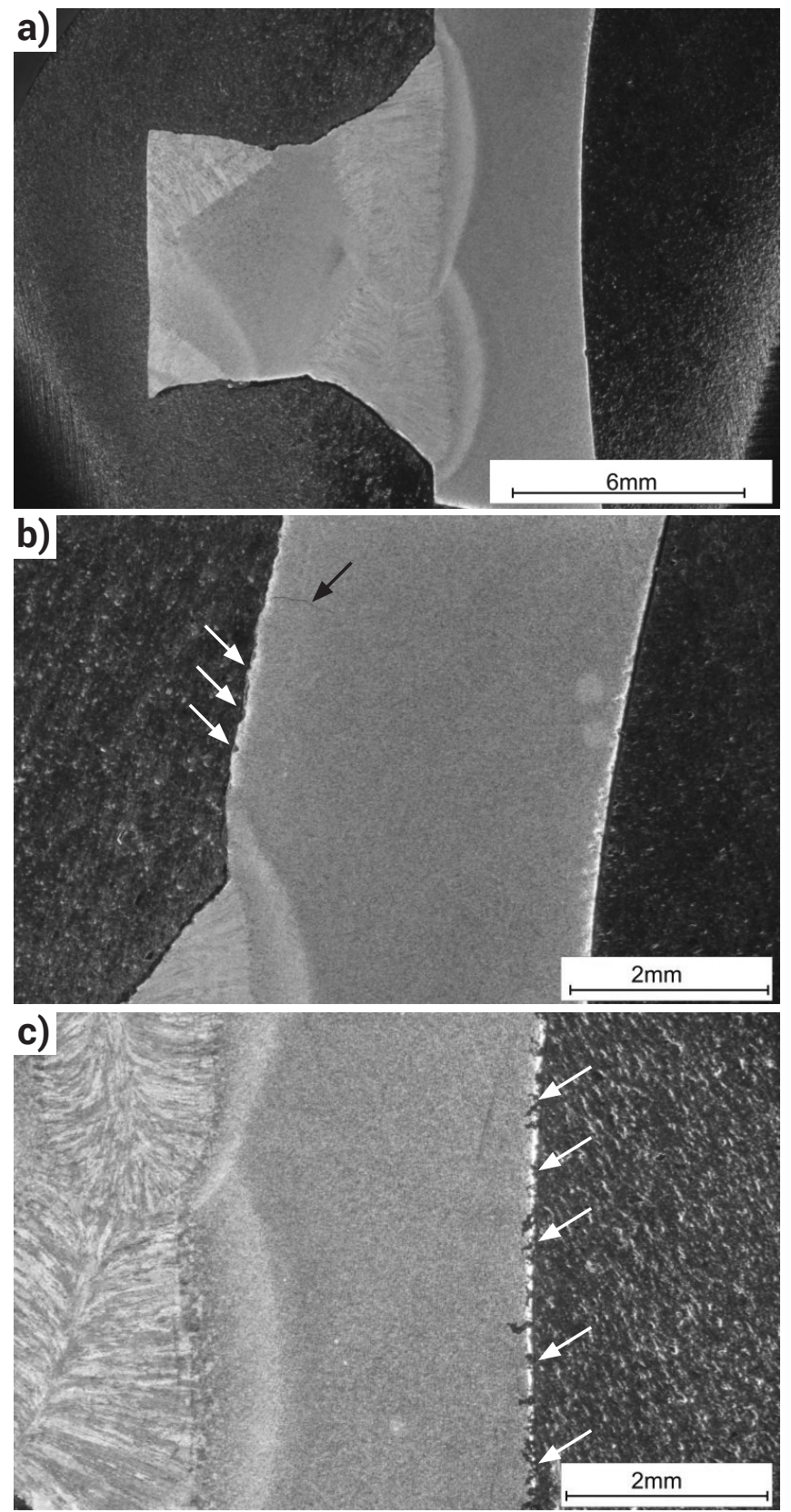

Rys. 4. Makrostruktura połączenia rura-płaskownik, SM: a) struktura złącza spawanego, b) pęknięcie w materiale rury poza złączem, c) ujawnione efekty korozji od strony wewnętrznej rury

Fig. 4. Tube-flat bar joint macrostructure, SM: a) structure of the welded joint, b) crack in the tube material outside of the welded joint, c) corrosion effects identified on the inside of the tube
JEOL JCM-6000 Neoscope II (SEM) w technice elektronów wtórnych SE, przy powiększeniach 50x $\div 1000 x$. Przykładowe struktury pokazano na rysunku 6.

Analiza wyników badań makrostruktury złącza spawanego rura-płaskownik nie ujawniła niezgodności spawalniczych (rys. 4a). Obserwowana struktura złącza jest prawidłowa. Złącze dwustronne charakteryzuje się prawidłowym gładkim licem, bez podtopień oraz pełnym przetopieniem. Szerokość strefy wpływu ciepła jest poniżej $1 \mathrm{~mm}$, co jest prawidłowe przy spawaniu hybrydowym MAG+Laser. Na podstawie badań makrostruktury stwierdzono, że złącze spawane w procesie hybrydowym MAG+Laser spełnia wymagania klasy B wg ISO 12932 w zakresie makrostruktury.

Na powierzchni rury, poza strefą złącza ujawniono pęknięcie, przebiegające od zewnętrznej strony rury w głąb materiału (rys. 4b). Pęknięcie o długości ok. 0,8 mm jest usytuowane w materiale rodzimym rury w odległości ok. 3,2 mm od końca spoiny i ok. 2,3 mm od końca strefy wpływu ciepła złącza. $\mathrm{Na}$ krawędzi rury od strony wewnętrznej ujawniono również liczne wżery korozyjne (rys. 4c). Wżery takie są również obecne na powierzchni zewnętrznej rury od strony spalin (rys. 4b).

Badania mikrostruktury materiału rodzimego rury ujawniły strukturę ferrytyczno-perlityczną w układzie pasmowym, typowym dla procesu walcowania. Strefa wpływu ciepła charakteryzowała się strukturą ferrytyczno-bainityczną o morfologii wynikającej z cyklu cieplnego spawania hybrydowego MAG+Laser (rys. 5a). Szerokość tej strefy jest mniejsza niż $1 \mathrm{~mm}$. Struktura spoiny jest również ferrytyczno-bainityczna w układzie kolumnowych ziaren austenitu pierwotnego.
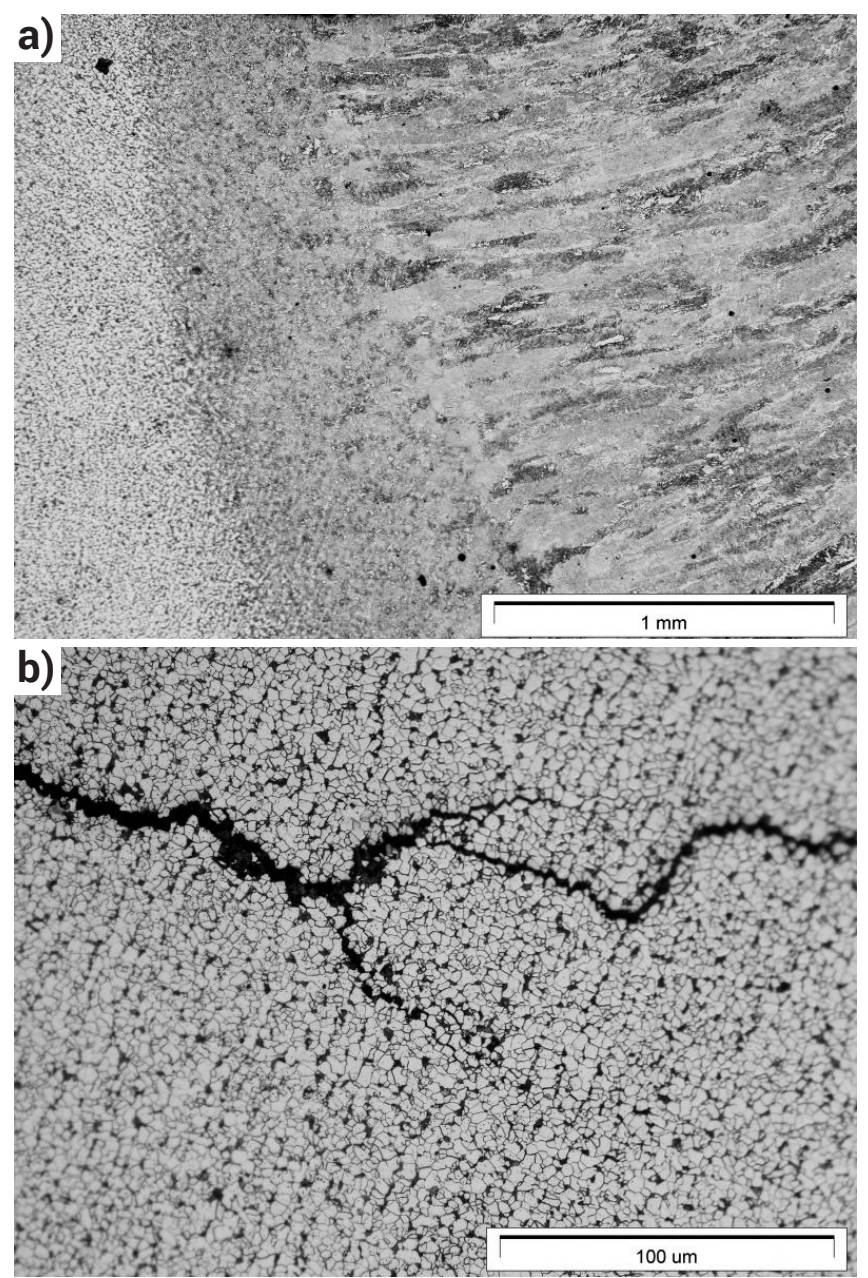

Rys. 5. Mikrostruktura obszaru złącza rura-płaskownik, LM: a) struktura spoiny, b) pęknięcie w materiale rury od strony spalin poza strefą złącza

Fig. 5. Tube-flat bar joint microstructure, LM: a) weld structure, b) crack in the tube material on the exhaust gas side, outside of the welded joint 

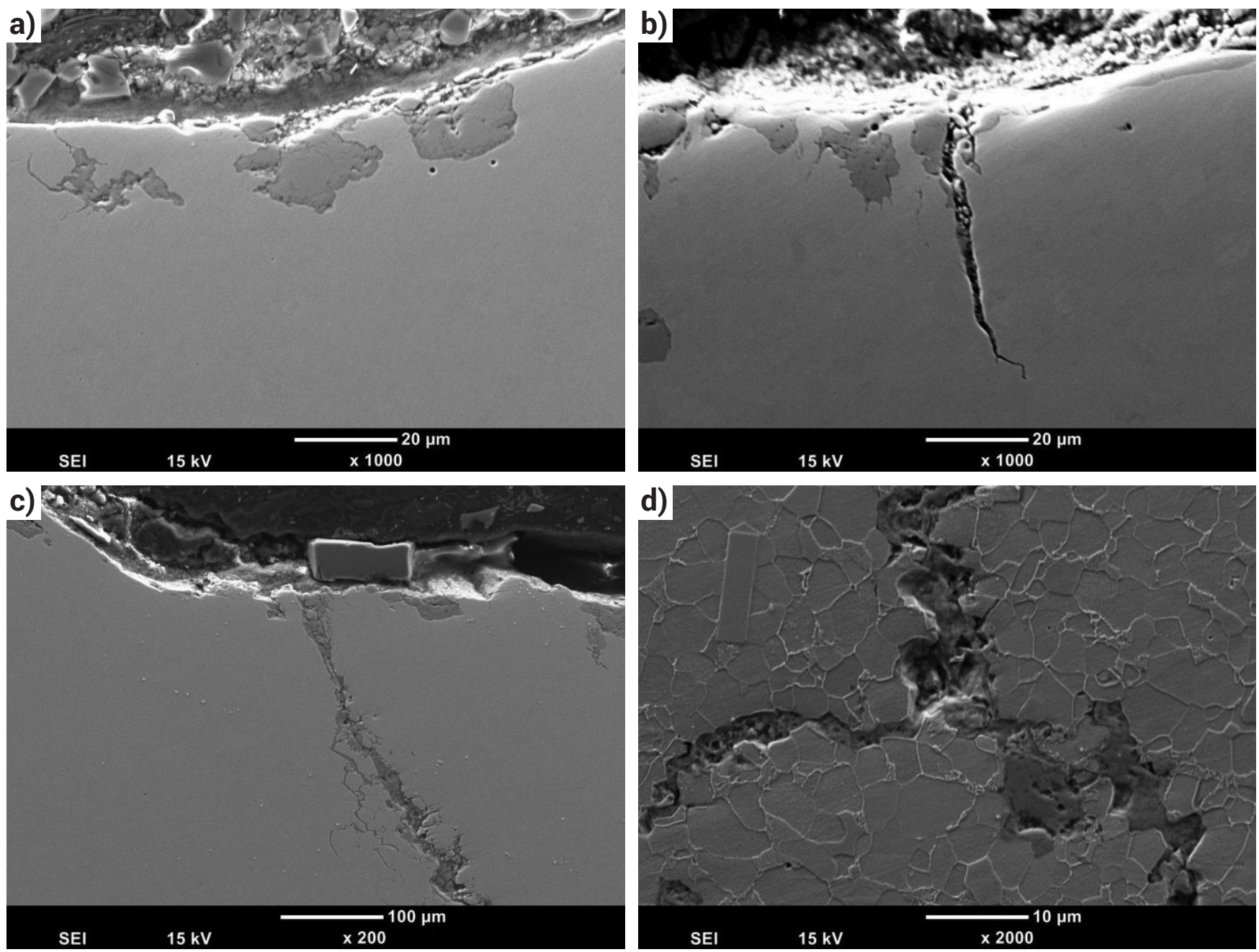

Rys. 6. Struktura przy krawędzi rury, SEM: a) wżery korozyjne na powierzchni rury, b) pęknięcie na powierzchni rury z produktami korozji i wżerami korozyjnymi wewnątrz materiału, c) pęknięcie inicjujące na powierzchni z widocznymi licznymi małymi pęknięciami odzłomowymi, d) miejsce rozgałęzienia pęknięcia z widocznymi produktami korozji

Fig. 6. Structure of the area beside the tube edge, SEM: a) corrosion pits on the tube surface, b) crack on the tube surface with corrosion products and corrosion pits inside the material, c) crack initiating on the surface with visible numerous small cracks propagating from it, d) site of crack branching with visible corrosion products

Ziarna te podczas krystalizacji narastały prostopadle do powierzchni stopienia w kierunku odprowadzenia ciepła (rys. 5a). Na podstawie przeprowadzonych badań metalograficznych stwierdzono, że mikrostruktura połączenia rura-płaskownik jest prawidłowa, nie ujawniono niezgodności spawalniczych np. w postaci przyklejeń lub innych nieciągłości.

Analiza mikrostruktury w pobliżu ujawnionego pęknięcia wskazuje, że pęknięcie rozwija się po granicach ziaren ferrytu i kolonii perlitycznych i ma charakter międzykrystaliczny na całej długości (rys. 6b). Ujawniono również pęknięcia odzłomowe. W tym obszarze pęknięcie ma charakterystyczną rozgałęzioną trajektorię, co wskazuje na pękanie związane z korozją naprężeniową. Na powierzchni rury zarówno od strony spalin, jak również od strony wewnętrznej obserwowano wżery korozyjne.

Przeprowadzone badania mikrostruktury na elektronowym mikroskopie skaningowym na zgładach nietrawionych i trawionych wskazują liczne wżery korozyjne (rys. 6a), od których inicjowały pęknięcia (rys. 6b). Potwierdza to również mikropęknięcie pokazane na rysunku $6 \mathrm{c}$.
Pęknięcia rozwijają się po granicach ziaren struktury ferrytyczno-perlitycznej (rys. 6d), co wskazuje na typowy charakter korozji naprężeniowej. W przestrzeni pęknięcia obserwowano produkty korozji (rys. 6c i 6d). Świadczy to o zbyt niskiej odporności materiału rodzimego na warunki eksploatacji lub nieprawidłową eksploatację instalacji.

\section{Pomiary twardości}

Badania twardości wykonano metodą Vickersa przy obciążeniu $98 \mathrm{~N}$ (HV10). Wyniki pomiarów przedstawiono na rysunku 7. Analiza rozkładu twardości wskazuje, że twardość materiału rodzimego rury jest na poziomie 156 HV10, w strefie wpływu ciepła od strony rury zakres twardości był od 180 do 187 HV10 (średnio 182 HV10), w spoinie zmierzono średnio 262 HV10, a w SWC od strony płaskownika twardość wynosiła 260 HV10, twardość płaskownika wynosiła 160 HV10. 

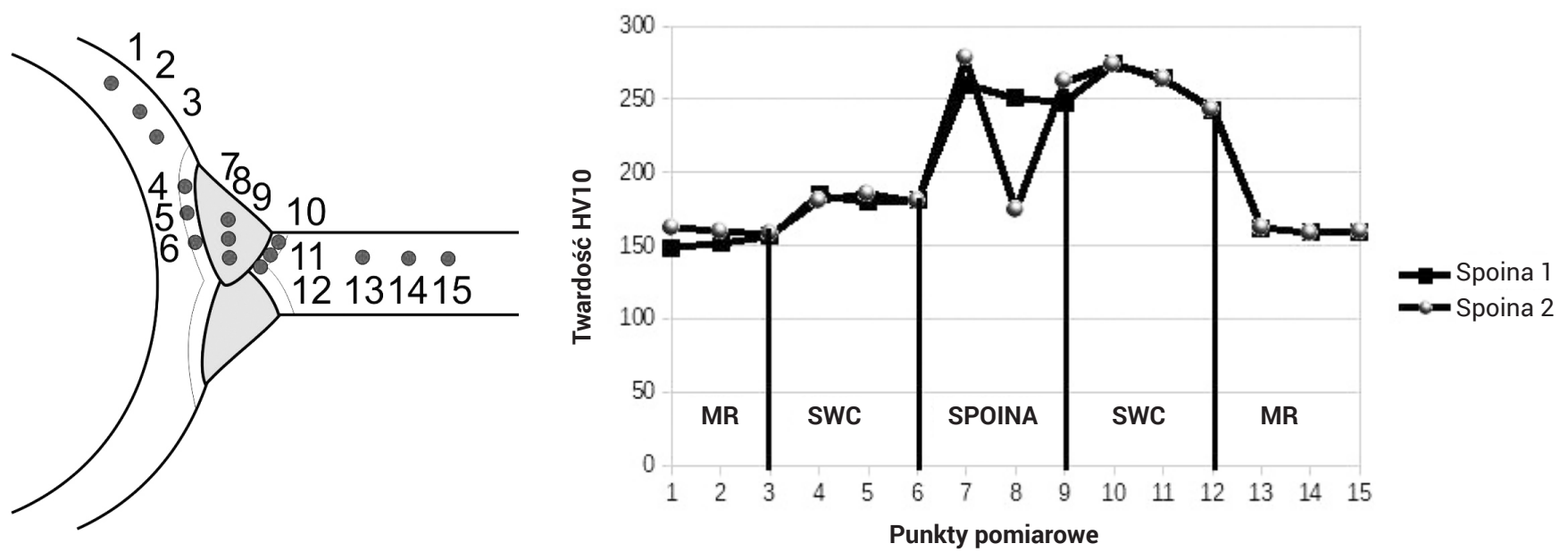

Rys. 7. Rozkład twardości w złączu rura-płaskownik spawanym hybrydowo MAG+Laser

Fig. 7. Hardness distribution in a laser+MAG hybrid welded tube-flat bar joint

\section{Wnioski}

Na podstawie przeprowadzonych badań oraz analizy ich wyników sformułowano następujące wnioski:

- Dwustronne złącze spawane rura-płaskownik ściany szczelnej badanych kotłów, wykonane metodą spawania hybrydowego Laser+MAG jest prawidłowe i spełnia wymagania klasy B wg ISO 12932.

- Struktura połączenia jest typowa dla spawania hybrydowego. Złącze jest zbudowane z trzech charakterystycznych stref tj. materiału rodzimego o strukturze ferrytyczno-perlitycznej w układzie pasmowym, ferrytyczno-bainitycznej strefy wpływu ciepła o morfologii zgodnej z cyklem cieplnym spawania (szerokość SWC jest poniżej $1 \mathrm{~mm}$ ) oraz spoiny o strukturze ferrytyczno-bainitycznej w układzie kolumnowych ziaren austenitu pierwotnego.

- Badania makro i mikrostrukturalne złącza nie ujawniły niezgodności spawalniczych w obszarze złącza, a rozkład twardości jest prawidłowy.

- Ujawnione pęknięcia rury znajdują się poza strefą zmian strukturalnych wywołanych procesem spawania hybrydowego (ok. 3,2 mm od końca spoiny i 2,3 mm od końca strefy wpływu ciepła), w strefie materiału o strukturze ziarnistej ferrytyczno-perlitycznej i nie są związane ze spawaniem połączenia rura-płaskownik.

- Pęknięcia są wynikiem procesu korozji naprężeniowej, ininicjowane są na wżerach korozyjnych na powierzchni rury od strony spalin i następnie rozwijają się po granicach ziaren w postaci pęknięcia głównego i pęknięć odzłomowych.

- Mechanizm zniszczenia rury w wyniku korozji naprężeniowej potwierdza również międzyziarnisty charakter przełomu pęknięcia i obecność produktów korozji wewnątrz pęknięcia.

\section{Literatura}

[1] Adamiec P., Adamiec J., Więcek M.: Spawanie hybrydowe MAG+laser włóknowy paneli ścian szczelnych, Spajanie metali i tworzyw w praktyce nr 4, 2007.
[2] PN EN ISO 12952-5:2011: Kotły wodnorurowe i urządzenia pomocnicze.

[3] VGB-R 501 H VGB Richtlinie fuer die Harstellung Und Bauueberwachung von Hochleistungsdampfkesseln 7. Ausgabe 1968. 